\title{
Evaluating the Customer Satisfaction's Effect on Murabahah and Mudarabah Financing in Islamic Banking
}

\author{
Bashir Baba ${ }^{1}$, Shafie Mohamed Zabri ${ }^{1}$, Ahmed Kaseri Ramin ${ }^{1}$ \\ ${ }^{1}$ Universiti Tun Hussein Onn Malaysia \\ 101 Beg Berkunci, Parit Raja, Batu Pahat, Johor, 86400, Malaysia
}

DOl: $10.22178 /$ pos. $42-2$

JEL Classification: E50

Received 30.08.2018

Accepted 27.01.2019

Published online 31.01.2019

Corresponding Author:

Bashir Baba

bashirababa@gmail.com

(c) 2019 The Authors. This

article is licensed under a

Creative Commons

Attribution 4.0 License

(c) (1)

\begin{abstract}
There are a considerable number of studies on the service quality dimensions of banking industries, but little researches were carried out on the product quality dimensions, and this led to the minimal understanding of the impact of product quality dimensions from the customers' standpoints, This research sought to identify the impact Islamic banking products (Murabahah and Mudarabah) dimensions on customer satisfaction. The study surveyed Islamic bank customers (users of the Islamic bank's products in Nigeria) using questionnaires to seek responses, a convenient sampling technique was conducted to reach out to customers, and the use of PLS-SEM 3 was employed for the analysis of the data. The result model shows an $R^{2}$ value of 0.414 (for Murabahah), which means $41 \%$ of the variance in customer satisfaction is explained by the exogenous constructs of perceived quality, cost, convenience and compliance of Murabahah, and $R^{2}$ value of 0.309 (for Mudarabah) which means $31 \%$ of the variance in customer satisfaction is explained by the exogenous constructs of perceived quality, cost, convenience and compliance of Mudarabah. The values of $R^{2}$ for Murabahah and Mudarabah show that the constructs were moderate in determining the satisfaction level of customers as they produced 0.414 and 0.309 respectively.
\end{abstract}

Keywords: Islamic bank; products; services; customer satisfaction.

\section{INTRODUCTION}

The banking institution is an organizational set up that provides financial services to the general public, and it is considered one of the essential institution in the economic arrangement of any given state [52]. Banks mainly provide all sorts of monetary transactions and the preservation of all other valuables for their clients [45]. There are mostly three types of banks which are; The Central banks, the Investment banks, and the retail banks. While the central banks oversee and regulate the activities of the retail banks, Investment banks deal with international and multi-national organizations. The retail or commercial banks conduct their operations directly to individuals and corporate institutions, and it is classified into two categories; conventional and Islamic banks. Both conventional and Islamic banks serve almost the same purposes except that Islamic bank operates principally on the sharing of profit and loss and also prohibits interest charges (riba) in all its activities. The evaluation of the impact of Islamic bank product quality dimensions on customer satisfaction is the primary objective of this study. The study surveyed Islamic banking customers from the Northern region of Nigeria. Among the standard products dealt within the Islamic banks are Profit and loss sharing (Mudarabah), safekeeping (Wadi'ah), a joint venture (Musharakah), cost plus (Murabahah) and leasing (Ijarah) [6]. The saving banking set up that is presently working in Nigeria is the conventional one which is an interest-based one, in which the entire credit structure is based upon the establishment of interest under which the borrower is committed to paying a prearranged rate/charges on the sum acquired regardless of the benefit or misfortune brought about.

The current connection between the bank and its customer under this framework is that of a loan boss and indebted person which prompted such a large number of monetary and societal ills in addition to other vices [14]. 
It was first presented in 1975 in Egypt, and from that point it grows to all edges of the globe. Islamic banking is a crucial piece of Islamic money related framework on a worldwide scale; it has encountered a quick progression from the time of commencement to be a lively and focused routine with regards to monetary intermediation in the global banking structure [31]. From the historical backdrop of starting business sector framework and early strategy for mercantilism which is considered Islamic free-enterprise that existed around the eighth and twelfth centuries, it had applied some economic theories and techniques in early Islamic banking which comprise the partnership (Mufawada), bill of exchange, forms of capital (Al-mal), and Limited partnership (Mudarabah) etc. [29]. According to [89], the evidence for the sustainability of Islamic banking can be seen in the fact that many conventional and some major multinational banks such as Citibank, HSBC, and Standard and Chartered banks have commenced practicing the Islamic banking system through the opening of Islamic banking windows. This is because of the prosperous operation of Islamic banking institutions and the experience in some countries like Iran, Malaysia, and Bahrain which adequately show that Islamic banks offer a substitute system of banking. Research also indicates that Islamic banking achieved a vivid progression, escalating to about 435 organizations functioning in 75 countries across the globe, which involves the major monetary hubs such as New York, London and so on [69]. Additionally, in the African continent like the Gambia, Ethiopia and Senegal are already having operational guidelines governing Islamic bank, while some others are at various phases of shaping and implementing their regulatory policies [86].

\section{LITERATURE REVIEW}

\section{Customer satisfaction}

Nigerian monetary markets experienced intense changes after monetary progression amid the mid-1990 that incite extreme rivalry among budgetary establishments, particularly in the banking industry. This opposition prompts the presentation of customer-oriented goods in the market to meet the desires for clients. The satisfaction of customers has been an essential part of every organization because of an expansion in the rivalry, and it is viewed as a pivotal component of shaping the intensity of banks [49].

Satisfaction is a post-buy assessment decision related to a particular consumption choice. The favorite way for the survival of any organization relies upon how it handles it is clients. Subsequently, a consistent assessment of the level of the contentment of clients in a systematic way is required [18, 54].

Researchers $[1,2]$ found that female clients execute lesser banking exchanges because of lower pay and other social hindrances. It is discovered that the gender part is influenced by particular social, cultural and religious elements. Male members do the majority of the financial deals and banking services in the Muslims countries $[27,43]$. The principal statute for fruitful rivalry in the market is consumer loyalty since it is the fundamental prerequisite for holding clients to make benefits. Consumer loyalty is essential in realizing business lucrativeness, a higher share of the market and more earnings from investments [15].

Customer satisfaction appears as the total aftereffect of clients' inward thoughts about their encounters identified with goods and services. It is commended that the business establishments particularly banks should focus on the ways to satisfying their customers [76]. And that can leads to rehashed buying manner that is inescapable for long time business achievement. An experimental outcome demonstrated a solid connection between perceived quality, consumer loyalty and different factors in Australia and Korean banks. Authors [57] emphasized that fulfillment is estimated by the contrast between apparent execution and cognizance's like desire and wants. As indicated by [36], consumer loyalty is a "multidimensional construct that requires a multi-thing scale for its estimation". Researchers concurred with the multidimensional idea of consumer loyalty and estimated it as needs be. Client total satisfaction is examined by utilizing a four-thing scale regarding service supplier [16].

Another investigation analyzed consumer loyalty by building up a five-thing scale to test their model [80]. So also, authors [17] explored consumer loyalty in managing an account area utilizing a six-thing scale. Also, authors [13] utilized a solitary thing scale to explore the conceptualization and estimation of service quality, and the connection between benefit quality, client satisfaction, and purchase intention, and their discov- 
eries were in this way, service quality is a base of purchaser fulfillment, and buyer fulfillment significantly affects buy expectations, and administration quality Lesly affects purchase intention than does consumer loyalty. Their approach was viewed as deficient because of the focus on just a single thing. Researchers [59] explored the connection between service quality and consumer loyalty in the banking industry and recommended five measurements of consumer loyalty, i.e., central administration or administration items; human component of administration conveyance; systemization of administration conveyance (non-human component); physical assets of services (service scale) and social obligation.

Several factors yield customer satisfaction with which service quality is one of them. Authors [50] described that the satisfying of customers hold clients for the higher productivity, higher portion of the overall industry and more rate of return. Moreover, authors [72] examined that service quality fills in as contribution to show up as consumer loyalty. Likewise, authors [48] found that customer satisfaction produces many results like rehash buy; unwaveringness, positive word of mouth and long lasting returns. Similarly critical, authors [66] discovered that there is an immediate and positive connection between perceived quality and level of fulfillment. Similarly, researchers [77] recommended that banks can make consumer loyalty by fusing reliable practices, appropriate correspondence of data, an impression of the veritable pledge to giving quality services, settlement of contentions and change in the nature of by and large client relations.

Also, authors [9] examined the effect of consumer loyalty in Malaysian saving money industry and found a $U$ formed the connection between clients' impression of fulfillment and positive verbal referrals in the presence of evolving possession. Basic condition displaying is one of the factual instruments connected to gauge consumer loyalty. The investigation depended on 220 clients from 15 business banks. Consumer loyalty was observed to be the key determinant of relationship quality. The essential pointers of consumer loyalty were recorded as trust, responsibility, correspondence, benefit quality, benefit fulfillment and administration taking care of [19].

Authors [39] explored consumer satisfaction in the banking industry in New Zealand. Discoveries demonstrated that consumer satisfaction is the most basic factor that impacts client choices. Clients' age sets and educational level equally added to their choice whether to remain with a present bank or not. Apparent from an overview of 230 retail-bank clients, that responsiveness and steady quality demonstrated the huge effect on consumer satisfaction in the United States [25]. An investigation found that fulfillment is basic for the maintenance of retail banking clients in the United Arab Emirate (UAE) [61].

Essentially, a different example of consumer satisfaction and social results is seen among male and female bank clients [80]. In another examination, discoveries demonstrated that there is the distinction in decision factors by male and female bank clients in the determination of their individual bank [82]. Authors [2] expressed that service quality fundamentally impacts the consumer loyalty if there should arise an occurrence of Islamic and conventional bank while the level of the impact is more critical in Islamic Banks when contrasted with Conventional Banks.

\section{Product quality}

The banking sector remains one of the areas that is being challenged with a total quality management theories and methodologies among service industries [11]. A customer oriented style to quality, espouse from such a thought, compels investigation on the needs of the customers [85]. This is reinforced for the reason that the nature of service, altogether intention is particular, unmistakable from the quality of items, which can be estimated experimentally. Thus an appropriate method for evaluating this component is to assess the views of the clients [55].

Estimating quality from this point of view has seen extremely slight consideration in the banking set up. Studying writing in this part demonstrated embracing a client mindfulness tactic to deal with quality estimation in the Islamic banking sector required a new framework which is more regular in each environment.

For a significantly long time, the rivalry has been a critical test looked by the organizations who need to deliver better quality items at a lower rate. To contend with any opponent organization, each organization embraced a joined administration thought, the accomplishment of which was shown by the inventive firms like keeping the banking industry [20]. The tactical significance of quality management practices has been admitted 
by both managers and researchers [28]. Current opinions about the swap and collective models of competitive priorities make managers and researchers differentiate quality as the basic competitive variable, in the absence of which, the remaining priorities like flexibility, dependability, and cost are difficult to realize [26, 35, 37].

Though quality management performance is studied in Toto, the connection between quality practices built on quality dimensions and perceptions of customers permits an added study [38, 51, 64]. This study starts with a review of the quality dimension and perspectives, in the literature. Then, it establishes a framework and four plans to explore and analyze the relationships between quality dimensions, perspectives, and practices.

\section{Islamic banking}

As indicated by [2], a bank is a financial foundation which manages credits, savings, and other related services. It gets cash from savers as deposits and loans it out to the individuals who require it. Banking is a transformative knowledge where it is incessant and enhancement as respects the capacities, services, and exercises of the bank [60]. Nonetheless, there are different sorts of banks which incorporate mortgage bank, Agriculture bank, commercial bank and Development banks. The structure of money related intermediation all inclusive observes a radical move in the course of the most recent couple of decades. The imposing business model status delighted in by the regular arrangement of keeping money and back changed with the rise of Islamic banking framework, which depends on the standards of the Shari'ah, i.e., Islamic law [70]. The Islamic structure turned out to be equipped for motivating genuine development, noninflationary development by a method for manufacturing collaboration in hazard assuming and benefit and misfortune sharing. Islamic bank is equipped for pulling in a huge pool of financial specialists and business visionaries, particularly in the casual division which has been estranged by the conventional banking framework.

Notwithstanding this sterling highlights, wide donation and gigantic achievement recorded by the Islamic bank and fund all-inclusive, the reception of the Islamic banking framework by the zenith budgetary establishment (The Central Bank of Nigeria, CBN), was welcomed with soak oppo- sition in specific quarters of the nation. Mitigating the feelings of dread communicated, the CBN focused on that the endeavour is a piece of its reaction to global patterns and a measure to exploit large money related assets, trading hands all inclusive. According to [78], business bank, consequently, is the monetary go-between which gathers credit from moneylenders as keep and loans as an advance. This sort of bank holds the store for people and business in the method for checking and investment account and testaments of the store of differing developments while a business bank issues credits in the game plan of individual and corporate advances and also contracts. There are also different kinds of the commercial bank such as Diamond bank, Access bank, as well as the recent non-interest bank (keystones, Stanbic IBTC etcetera), and the noninterest banking scheme which is recently integrated into the banking system. Islamic finance and the Shari'ah-compliant's financial products that constitute the fundamentals of Islamic banking have developed to be among the fastest improving fragments of the money market industry, functioning in not less than 300 institutions in 75 nations across the globe [75].

Economists are of the view that the two central apparatuses through which economic growth can be sustained or crushed are financial and legal systems [56].

Nevertheless, empirical proof concerning the influence of the Islamic banking system on monetary development still cannot seem to be broken down in detail to a great extent because of information impediments. Certain segments of Islamic banking, for example, risk sharing, steadiness, and advancement are demonstrated stimulants for growth while others, including limited liquidity, may be detrimental to the economy. Therefore, the products of Islamic banking likely impact economic growth, the effect of which is uncertain and worthy of study [68].

The establishment of legal origin as a significant element of progression in the economic and financial sectors, an Islamic bank is also a derivative of a statutory root which is known as Shari'ah Law, and it is regularly differentiated from that of the other institutions in the operating countries. While researchers have postulated that this occurrence could change the effect of legal origin on development [44]. 


\section{The concept of Islamic banking}

According to [44], Islamic banking refers to as Shari'ah-compliant banking that provides and uses financial products and services that obey the Islamic religious practices and laws. The doctrines which have to emphasize moral and ethical values in all dealings have wide universal appeal. Shari'ah outlaws the giving or receiving interest charges (Riba) for the loaning and acceptance of money, as well as engaging in trading activities that provide goods and services considered contrary to its principles. Islamic banking refers to a technique of banking that is founded on Islamic law (Shari'ah), which prohibits 'interest-based banking' and permits only 'profit sharing banking' [7]. The root of the concept is stated in the Holy Qur'an where it says; "Allah has allowed only legitimate trade and prohibited interest," (Qur'an 2 v 275). It is against this interest, as interest is believed to lead to the exploitation and unproductive income. Islamic and conventional banking serve the same purpose except that it operates by the rules of Shari'ah, known as Fiqh al-Muamalat (Islamic rules on transactions).

Therefore, by Islamic banking, one does not mean a mere lending institution extending interest-free loans, but a package of Shari'ahcompliant (strict adherence to Islamic economic norms) financial services such as Islamic mutual funds, Islamic bonds (Sukuk), Islamic insurance (Takaful), Islamic credit cards and other technology-driven services like Automated Teller Machines (ATMs) and online banking, all of which have a tremendous market in the world. Author [5] describes non-interest banking as "a form of banking which conducts banking operation, involves in exchange, investment and commercial activities as well as providing financial products and services by the principles and rules of Islamic jurisprudence". The basic element of trust and financial partnering are the things that account for the uniqueness of non-interest banking. According to [78] Islamic bank is "a bank or other financial institution (OFI) under the Central Bank of Nigeria (CBN) which implements banking business, engages in trading investment and commercial undertakings as well as provision of financial products and services in accordance with the ideologies and rules of Islamic commercial jurisprudence".

\section{Empirical studies}

There has been an increasing interest in perception and patronage studies of Islamic Banks in recent years, to elicit customer and other stakeholders' opinions and views toward the operation of Islamic banks. Previous work like [2] is some of the research carried out in the discipline. Notwithstanding, the progress made to date in the study of customer perceptions towards Islamic bank, the more focused research studying the perceptions of Nigerian stakeholders in IBs seems inexistent. Similar opinion could hold for another area of IBs like corporate social responsibility (CSR), Qardul-Hassan, product innovation and development, corporate governance, human resource and host of other critical areas of noninterest banking, More so, that non-interest banking is just about to be established despite almost two decades of struggle on the project. Therefore it is imperative to examine the perception of a potential customer, staffers, and major stakeholders of non-interest banking, notably that the establishment and operation of noninterest banking in the country has reached a more advanced stage according to [42].

Against this background, the studies by $[32,33]$ are often regarded as the earliest patronage studies on Islamic banking which used both conventional and Islamic customers. The customer who patronized Islamic bank perceived the three most important criteria in bank selection, which are the delivery of fast and efficient service, bank reputation, and image and confidentially. Similarly, a study by [47] revealed that the correlation of Islamic bank and financial deepening is mostly dependent on legitimate origin resulting in negative effects for nations with British legal foundation and positive for countries with French legal origin. Another study by [63] argued that the principles of Islamic banking are not followed. Accordingly, the rules are violated in the process.

Author [8] postulated that the opportunities noninterest finance institutions have in Nigeria which among others offer avenues for the flow of cross-border capital, financial market deepening, and financial inclusion in both Muslim and Christian majority countries. Authors [62] asserted that Muslim customers have a strong desire for gathering information concerning Islamic bank and finance, with the intention of patronizing the products and services of the bank. Authors [12] found that only the bank size is significant in determining the profitability with a positive rela- 
tionship. Authors [83] highlighted the challenges facing Islamic banks as economic, region, public acceptance, rules and regulation and human resources, though these cannot always be the case because if the regulating agency in one country does not favour or create room for harmonious operation of Islamic banks, of course, others can be found with conducive rules for Islamic banking operation. Results of a study by [88] suggested that Islamic banking suffer slight inefficiencies during the global financial crisis of 1998-1999 because of the exclusion of speculation in the Islamic banking system, which [81] inferred that there exists a significant effect of the emergence of Islamic banking in resolving economic instability in Nigeria.

Author [67] proved that the introduction of Islamic banking products into the Nigerian banking system is lawful and it benefits the country by strengthening the countries financial sector. $\mathrm{Au}-$ thor [63] found that the operations of Islamic and conventional banks are not the same, but similar to each other, highlighting the differences in the systems. Authors [1] reflected an updated picture of Pakistani banking sector since independence and they concluded that readers, academicians, and bankers have to look about banking developments in Pakistan as the journey from conventional to Islamic banking to enhance their understanding.

Researchers [65] stressed that the need for proper sensitization and educating the Nigerian populace to enable them distinctly demarcate between the provision draft and real Islamic paradigm of banking. Authors [41] also revealed that the three important selection criteria perceived and used by Muslim customers in Malaysia when selecting their banks were personal friendliness, provision of a fast and efficient survive and the speed to traction. The study made a significant contribution by identifying the individual customer potential in patronizing a noninterest bank (Islamic bank). A survey by [84] on the perception of non-interest banking or Islamic banking management on quality of service to customers revealed that customer perspective is of significance to Islamic banking operation. Thus, their findings noted that customers were unsatisfied with the quality of Islamic bank service and also from the management perspective services quality was believed to be below expectations.

However, a similar study by [2] examined the perception of bank customers regarding the ser- vice quality of Islamic banks as well as conventional banks in Nigeria. Their study revealed that customer perception of non-interest banks is higher than that of conventional banks which as a result of interest-free products, risk sharing practices and strong ties to the religion. This submission was earlier confirmed by [41] when they found that non-interest banking products and services have good potential to be accepted by customers.

\section{Data analysis and technique}

Practically, the data collected using the questionnaire were edited by a comprehensive check to make sure that the questions asked were clear for the respondents understanding. Also, after the process of editing data, the questionnaires will be coded for computer input.

According to [79], data collected using questionnaires are considered as raw data, which have to be inserted into the computer using a software called the Statistical Package for Social Science (SPSS), a software used for the analysis of quantitative data to obtain the final results of the study. The statistical methods are used to analyze the data collected. The SPSS aims at transforming of the raw data into a form that will make them easy to understand and interpret. Accordingly, in this research, the questionnaire data were codified and entered into a spreadsheet in SPSS version 23.0, and the data analysis was done using Univariate descriptive analysis prior to the inferential analysis of PLS-SEM. Consequently, the coding process was in the form of Likert scale: Number ' 1 ' for strongly disagree, ' 2 ' for Disagree, '3' for Neutral, '4' for Agree, and '5' for Strongly Agree.

\section{Factor Analysis}

A Principal Component Analysis (PCA) was conducted on all the constructs that made up of 76 items with orthogonal rotation (varimax). The respective Kaiser-Meyer-Olkin (KMO) of the extracted five components with the values of the acceptable limit of .5 which verified that the sample is adequate for the analysis [34]. The Bartlett's test of sphericity $\mathrm{X}^{2}$ were all less than $0.5(\mathrm{p}<.000)$, indicating that correlations between items were sufficiently large for PCA. An initial analysis was run to obtain eigenvalues for each component in the data. Table 1 shows the factor loadings after rotation. 
Table 1

\begin{tabular}{|c|c|c|c|c|c|}
\hline \multicolumn{2}{|c|}{ Constructs } & Items & $\begin{array}{c}\text { Factor } \\
\text { Loadings }\end{array}$ & $\begin{array}{l}\text { Total Variance } \\
\text { Explained }\end{array}$ & KMO \\
\hline \multirow{4}{*}{ 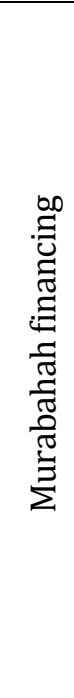 } & 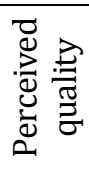 & $\begin{array}{l}\text { MPQ1 } \\
\text { MPQ2 } \\
\text { MPQ3 } \\
\text { MPQ4 }\end{array}$ & $\begin{array}{l}.631 \\
.821 \\
.811 \\
.716\end{array}$ & 56.06 & .647 \\
\hline & $\begin{array}{l}\overrightarrow{\tilde{\nu}} \\
0\end{array}$ & $\begin{array}{l}\text { MCO1 } \\
\text { MCO2 } \\
\text { MCO3 }\end{array}$ & $\begin{array}{l}.836 \\
.917 \\
.808\end{array}$ & 73.09 & .646 \\
\hline & 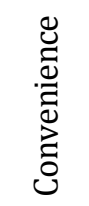 & $\begin{array}{l}\text { MCV1 } \\
\text { MCV2 } \\
\text { MCV3 }\end{array}$ & $\begin{array}{l}.523 \\
.828 \\
.801\end{array}$ & 53.38 & .556 \\
\hline & 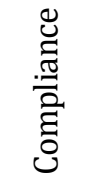 & $\begin{array}{l}\text { MCP1 } \\
\text { MCP2 } \\
\text { MCP3 }\end{array}$ & $\begin{array}{l}.689 \\
.907 \\
.797\end{array}$ & 64.39 & .546 \\
\hline
\end{tabular}

All items in each component load on one factor which indicates that these components represent the respective constructs. Table 2 presents the factor Loadings, TVE, and KMO for the Murabahah constructs.

Table 2

\begin{tabular}{|c|c|c|c|c|c|}
\hline \multicolumn{2}{|c|}{ Constructs } & Items & $\begin{array}{c}\text { Factor } \\
\text { Loadings }\end{array}$ & $\begin{array}{l}\text { Total Variance } \\
\text { Explained }\end{array}$ & KMO \\
\hline \multirow{4}{*}{ 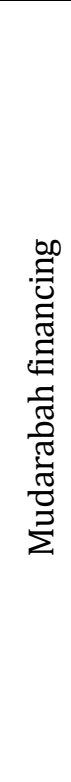 } & 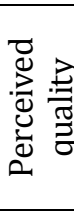 & $\begin{array}{l}\text { DPQ1 } \\
\text { DPQ2 } \\
\text { DPQ3 } \\
\text { DPQ4 } \\
\text { DPQ5 }\end{array}$ & $\begin{array}{l}.715 \\
.702 \\
.911 \\
.780 \\
.512\end{array}$ & 54.09 & .600 \\
\hline & 峁 & $\begin{array}{l}\text { DCO1 } \\
\text { DCO2 } \\
\text { DCO3 } \\
\text { DCO4 } \\
\end{array}$ & $\begin{array}{l}.579 \\
.911 \\
.902 \\
.599 \\
\end{array}$ & 58.47 & .664 \\
\hline & 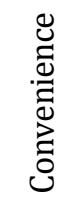 & $\begin{array}{l}\text { DCV1 } \\
\text { DCV2 } \\
\text { DCV3 }\end{array}$ & $\begin{array}{l}.901 \\
.904 \\
.715\end{array}$ & 71.37 & .633 \\
\hline & 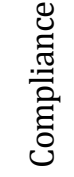 & $\begin{array}{l}\text { DCP1 } \\
\text { DCP2 } \\
\text { DCP3 }\end{array}$ & $\begin{array}{l}.560 \\
.787 \\
.727\end{array}$ & 48.72 & \begin{tabular}{|l|}
.557 \\
\end{tabular} \\
\hline
\end{tabular}

\section{Reliability Analysis}

It is prescribed that after recognizing the fundamental structure of the information through the EFA, an unwavering quality examination be led to additionally set up the dependability and legitimacy of the develops and by expansion the questionnaire $[53,62]$. The reliability of the constructs is verified applying the Cronbach's Alpha strategy. The standard limit for scale reliability is
.70 or more, even though .60 is additionally viewed as adequate when the investigation is at its exploratory stage $[34,62]$. Table 3 shows the result of the reliability analysis.

Table 3

\begin{tabular}{|c|c|c|c|c|}
\hline \multicolumn{2}{|c|}{ Constructs } & Items & $\begin{array}{c}\text { Items Cronbach } \\
\text { Alpha }\end{array}$ & $\begin{array}{c}\text { Scale Cronbach } \\
\text { Alpha }\end{array}$ \\
\hline \multirow{4}{*}{ 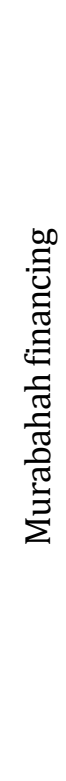 } & 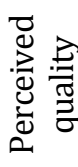 & $\begin{array}{l}\text { MPQ1 } \\
\text { MPQ2 } \\
\text { MPQ3 } \\
\text { MPQ4 }\end{array}$ & $\begin{array}{l}.769 \\
.648 \\
.633 \\
.710\end{array}$ & .753 \\
\hline & 苍 & $\begin{array}{l}\text { MCO1 } \\
\text { MCO2 } \\
\text { MCO3 } \\
\text { MCO4 }\end{array}$ & $\begin{array}{l}.621 \\
.602 \\
.657 \\
.893\end{array}$ & .778 \\
\hline & 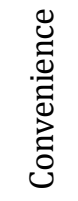 & $\begin{array}{l}\text { MCV1 } \\
\text { MCV2 } \\
\text { MCV3 }\end{array}$ & $\begin{array}{l}.855 \\
.696 \\
.813\end{array}$ & .850 \\
\hline & 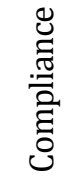 & $\begin{array}{l}\text { MCP1 } \\
\text { MCP2 } \\
\text { MCP3 }\end{array}$ & $\begin{array}{l}.831 \\
.631 \\
.768\end{array}$ & .815 \\
\hline
\end{tabular}

The reported Scale's Cronbach's Alpha indicated that all the scales are reliable as they all meet up the threshold. The Customer satisfaction subscale reported the highest alpha value $(\alpha=.978)$ while Wadiah perceived quality reported the lowest alpha of value of $(\alpha=.748)$. The reported alpha value of the remaining scales also satisfied the recommended threshold of .70 as shown in Table 4.

Table 4

\begin{tabular}{|c|c|c|c|c|}
\hline \multicolumn{2}{|c|}{ Constructs } & Items & $\begin{array}{c}\text { Items Cronbach } \\
\text { Alpha }\end{array}$ & $\begin{array}{c}\text { Scale Cronbach } \\
\text { Alpha }\end{array}$ \\
\hline \multirow{4}{*}{ 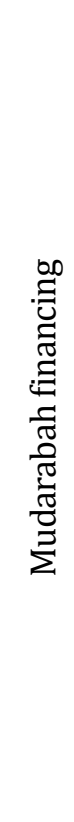 } & 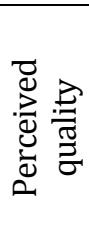 & $\begin{array}{l}\text { DPQ1 } \\
\text { DPQ2 } \\
\text { DPQ3 } \\
\text { DPQ4 } \\
\text { DPQ5 } \\
\text { DPQ6 }\end{array}$ & $\begin{array}{l}.709 \\
.722 \\
.635 \\
.681 \\
.730 \\
.778\end{array}$ & .750 \\
\hline & 苞 & $\begin{array}{l}\text { DCO1 } \\
\text { DCO2 } \\
\text { DCO3 } \\
\text { DCO4 }\end{array}$ & $\begin{array}{l}.812 \\
.755 \\
.751 \\
.919\end{array}$ & .856 \\
\hline & 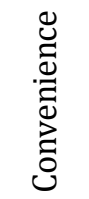 & $\begin{array}{l}\text { DCV1 } \\
\text { DCV2 } \\
\text { DCV3 }\end{array}$ & $\begin{array}{l}.625 \\
.617 \\
.873\end{array}$ & .791 \\
\hline & 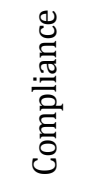 & $\begin{array}{l}\text { DCP1 } \\
\text { DCP2 } \\
\text { DCP3 }\end{array}$ & $\begin{array}{l}.779 \\
.836 \\
.771\end{array}$ & .854 \\
\hline
\end{tabular}




\section{Analysis of Response Rate}

The survey was conducted in 3 states of the Northern part of Nigeria, with a total of 400 customers who maintain accounts with Ja'iz bank Nigeria Plc. 400 questionnaires were distributed during the survey. The sampled branches are Ja'iz bank Bauchi branch, Gombe branch, and Yola branch. However, as illustrated in Table 5, out of the (returned number) of questionnaires, a total number of 303 questionnaires were retained as found valid for the analysis.

Table 5 - Response Analysis

\begin{tabular}{|l|c|c|}
\hline \multicolumn{1}{|c|}{ Item } & Frequency & $\%$ \\
\hline $\begin{array}{l}\text { Total distributed } \\
\text { questionnaire }\end{array}$ & 400 & 100 \\
\hline $\begin{array}{l}\text { Total returned } \\
\text { questionnaire }\end{array}$ & 336 & 84 \\
\hline $\begin{array}{l}\text { Total rejected } \\
\text { questionnaire }\end{array}$ & 33 & 8.5 \\
\hline $\begin{array}{l}\text { Total usable } \\
\text { questionnaire }\end{array}$ & 303 & 75 \\
\hline
\end{tabular}

After the data collection, the information obtained was coded and entered into a Statistical Package for Social Sciences (SPSS) software. A total of 33 responses were rejected and excluded from the coding process because of incomplete pages, hence, a total of 33 questionnaires were removed while 303 retained and used for further analysis. The removal of such outliers was informed from the reasoning that extreme outlier cases usually affect the distribution of dataset thereby affecting the result of the analysis [71]. Thus, it is expected that the removal of an outlier, in this case, will improve the result of this study.
This response rate is considered adequate for this research based on the argument of [79], that response rate of 30 percent is acceptable for surveys. The rate is also considered adequate based on the recommendation that the sample size should be 5 to 10 times the number of variables in a study [40]. Moreover, since this study is utilizing PLS, which requires a minimum of 30 responses [22], and particularly as Nigerian phenomenon of low response rate in social science studies, this study's 75 percent response rate falls within the adequate range [41].

\section{RESULTS AND DISCUSSION}

This section describes the data collected in tabular form using frequency, percentages, mean. It gives the overall outlook of the data and all the research constructs.

Respondents' level of satisfaction with the perceived quality of Murabahah is measured by four items coded from MPQ1 to MPQ4 as presented in Table 6.

The satisfaction of the of the respondents on the perceived quality of Murabahah revealed that $43 \%$ are satisfied, $15 \%$ are not satisfied, while $42 \%$ were not decided with the availability of the needed items for Murabahah (trust financing). On the process of assessing the Murabahah items, $57 \%$ are satisfied that the process is fast, $32 \%$ were not decided, while $11 \%$ disagree. On the quality of the items, $45 \%$ are satisfied with the quality, $34 \%$ were Neutral while $21 \%$ were not satisfied with the quality of the items under Murabahah arrangement.

Table 6 - Respondents level of satisfaction with the perceived quality of Murabahah

\begin{tabular}{|c|c|c|c|c|c|c|c|}
\hline Code & Statements & $\mathrm{SD}=1$ & $\mathrm{D}=2$ & $\mathrm{~N}=3$ & $A=4$ & $\mathrm{SA}=5$ & Mean \\
\hline \multirow[t]{2}{*}{ MPQ1 } & \multirow{2}{*}{$\begin{array}{l}\text { There is the availability of needed items for } \\
\text { Murabahah financing }\end{array}$} & 7 & 39 & 127 & 102 & 28 & \multirow[t]{2}{*}{3.74} \\
\hline & & $2.3 \%$ & $12.9 \%$ & $41.9 \%$ & $33.7 \%$ & $9.2 \%$ & \\
\hline \multirow{2}{*}{ MPQ2 } & \multirow{2}{*}{ The process of assessing the items is fast } & 1 & 34 & 96 & 146 & 26 & \multirow[t]{2}{*}{2.83} \\
\hline & & $0.3 \%$ & $11.2 \%$ & $31.7 \%$ & $48.2 \%$ & $8.6 \%$ & \\
\hline \multirow[t]{2}{*}{ MPQ3 } & \multirow[t]{2}{*}{ The items are of good quality } & 4 & 59 & 104 & 94 & 42 & \multirow[t]{2}{*}{3.89} \\
\hline & & $1.3 \%$ & $19.5 \%$ & $34.3 \%$ & $31.0 \%$ & $13.9 \%$ & \\
\hline \multirow[t]{2}{*}{ MPQ4 } & \multirow[t]{2}{*}{ The items are provided on time } & 4 & 29 & 105 & 115 & 49 & \multirow[t]{2}{*}{2.79} \\
\hline & & $1.3 \%$ & $9.6 \%$ & $34.8 \%$ & $38.1 \%$ & $16.2 \%$ & \\
\hline \multicolumn{2}{|c|}{ Aggregates } & & & & & & 3.31 \\
\hline
\end{tabular}

Notes: 1 - Strongly Disagree (SD); 2 - Disagree (D); 3 - Neutral (N); 4 - Agree (A); 5 - Strongly Agree (SA) 
The customers were satisfied with the provision of the Murabahah items on the designated time as $54 \%$ agreed that they supplied it on time, 39 $\%$ were not decided, while $11 \%$ were not satisfied. The aggregate mean score revealed 3.31 which implies that on the overall items of per- ceived quality of Murabahah are moderately satisfied.

Respondents' level of satisfaction with the cost of Murabahah is measured by four items coded from MCO1 to MCO4 as presented in Table 7.

Table 7 - Respondents rating of satisfaction with the cost of Murabahah

\begin{tabular}{|c|c|c|c|c|c|c|c|}
\hline Code & Statements & $\mathrm{SD}=1$ & $\mathrm{D}=2$ & $\mathrm{~N}=3$ & $A=4$ & $\mathrm{SA}=5$ & Mean \\
\hline \multirow[t]{2}{*}{ MCO1 } & \multirow[t]{2}{*}{ The amount of the needed item is bearable } & 5 & 37 & 108 & 123 & 30 & \multirow[t]{2}{*}{2.98} \\
\hline & & $1.7 \%$ & $12.2 \%$ & $35.6 \%$ & $40.6 \%$ & $9.9 \%$ & \\
\hline \multirow[t]{2}{*}{$\mathrm{MCO} 2$} & \multirow[t]{2}{*}{ The profit margin is not too high } & 6 & 12 & 94 & 105 & 86 & \multirow[t]{2}{*}{2.71} \\
\hline & & $2.0 \%$ & $4.0 \%$ & $31.0 \%$ & $34.7 \%$ & $28.4 \%$ & \\
\hline \multirow[t]{2}{*}{$\mathrm{MCO3}$} & \multirow{2}{*}{$\begin{array}{l}\text { The duration of the instalment payment is } \\
\text { acceptable }\end{array}$} & 9 & 31 & 53 & 95 & 115 & \multirow[t]{2}{*}{2.80} \\
\hline & & $3.0 \%$ & $10.2 \%$ & $17.5 \%$ & $31.4 \%$ & $38.0 \%$ & \\
\hline \multirow[t]{2}{*}{$\mathrm{MCO} 4$} & \multirow[t]{2}{*}{ Charges involved is high } & 16 & 20 & 60 & 68 & 139 & \multirow[t]{2}{*}{2.75} \\
\hline & & $5.3 \%$ & $6.6 \%$ & $19.8 \%$ & $22.4 \%$ & $45.9 \%$ & \\
\hline \multicolumn{2}{|c|}{ Aggregates } & & & & & & 2.81 \\
\hline
\end{tabular}

Notes: 1 - Strongly Disagree (SD); 2 - Disagree (D); 3 - Neutral (N); 4 - Agree (A); 5 - Strongly Agree (SA)

Table 7 revealed the respondents' satisfaction on the cost chargeable in Murabahah; the respondents agree that the amount of the needed item is bearable by $50 \%$, $35 \%$ were Neutral while $14 \%$ were not in agreement to the price of the items being normal. The profit margin added by the bank on original price is not too high, it is agreed upon by the $63 \%$ of the customers that the added profit margin is not too high, $31 \%$ were Neutral to that effect while $6 \%$ disagree. On the duration of the repayment, $69 \%$ agree that it is acceptable $17 \%$ were not decided, and $13 \%$ disagree with the acceptability of the span of time for the repayment, and on administrative charges involved in contracting Murabahah, $68 \%$ agreed that it is higher, while $19 \%$ were Neutral and 13 $\%$ disagreed with that statement. Going by the aggregate mean score of all the items, the mean score of 2.81 falls within the region of moderate, which signifies that the customers are averagely or moderately satisfied with the cost incurred in using Murabahah financing contract.

Respondents' level of satisfaction with the convenience of using Murabahah is measured by three items coded from MCV1 to MCV3 as presented in Table 8.

Table 8 - Respondents level of satisfaction with the convenience in using Murabahah

\begin{tabular}{|c|c|c|c|c|c|c|c|}
\hline Code & Statements & $\mathrm{SD}=1$ & $\mathrm{D}=2$ & $\mathrm{~N}=3$ & $A=4$ & $\mathrm{SA}=5$ & Mean \\
\hline \multirow[t]{2}{*}{ MCV1 } & \multirow[t]{2}{*}{ I feel convenient using the item supplied } & 16 & 12 & 41 & 145 & 89 & \multirow[t]{2}{*}{2.83} \\
\hline & & $5.3 \%$ & $4.0 \%$ & $13.5 \%$ & $47.9 \%$ & $29.4 \%$ & \\
\hline \multirow[t]{2}{*}{ MCV2 } & \multirow[t]{2}{*}{ The item meets my specifications } & 17 & 5 & 61 & 151 & 69 & \multirow[t]{2}{*}{2.70} \\
\hline & & $5.6 \%$ & $1.7 \%$ & $20.1 \%$ & $49.8 \%$ & $22.8 \%$ & \\
\hline \multirow[t]{2}{*}{ MCV3 } & \multirow{2}{*}{ I am convenient with the whole process } & 6 & 17 & 71 & 138 & 70 & \multirow[t]{2}{*}{2.91} \\
\hline & & $2.0 \%$ & $5.6 \%$ & $23.4 \%$ & $45.5 \%$ & $23.1 \%$ & \\
\hline \multicolumn{7}{|c|}{ Aggregates } & 2.81 \\
\hline
\end{tabular}

Notes: 1 - Strongly Disagree (SD); 2 - Disagree (D); 3 - Neutral (N); 4 - Agree (A); 5 - Strongly Agree (SA)

Responses on the convenience of the customers in using Murabahah indicate that $77 \%$ agree that they feel convenient in using the items supplied by Ja'iz bank under Murabahah contract, $14 \%$ maintain neutrality in their responses while $9 \%$ disagree with the statement to that effect, $72 \%$ and $69 \%$ also agree that the supplied items meet their specification, and they are convenient with 
all the processes of the contracts respectively, while $20 \%$ and $23 \%$ were undecided to that effect and $7 \%$ and $8 \%$ respectively disagree that they feel convenient in using the items supplied and also not convenient with the whole process of the Murabahah contract. And the aggregate mean score of 2.81 also determines that they are moderately satisfied with conveniences in using items acquired under Murabahah contract.

Respondents' level of satisfaction with the compliance of Murabahah is measured by three items coded from MCP1 to MCP3 as presented in Table 9 .

Table 9 - Respondents level of satisfaction with the compliance of Murabahah

\begin{tabular}{|c|c|c|c|c|c|c|c|}
\hline Code & Statements & $\mathrm{SD}=1$ & $\mathrm{D}=2$ & $\mathrm{~N}=3$ & $A=4$ & $\mathrm{SA}=5$ & Mean \\
\hline \multirow[t]{2}{*}{ MCP1 } & \multirow{2}{*}{$\begin{array}{l}\text { There is no uncertainty (gharar) in the process of } \\
\text { this transaction }\end{array}$} & 9 & 11 & 37 & 124 & 119 & \multirow[t]{2}{*}{2.90} \\
\hline & & $3.0 \%$ & $3.7 \%$ & $12.3 \%$ & $41.2 \%$ & $39.5 \%$ & \\
\hline \multirow[t]{2}{*}{ MCP2 } & \multirow[t]{2}{*}{ There is no interest rate charged } & 9 & 12 & 31 & 139 & 110 & \multirow[t]{2}{*}{2.58} \\
\hline & & $3.0 \%$ & $4.0 \%$ & $10.3 \%$ & $46.2 \%$ & $36.5 \%$ & \\
\hline \multirow[t]{2}{*}{ MCP3 } & \multirow{2}{*}{$\begin{array}{l}\text { The items supplied are always in accordance with } \\
\text { Shari'ah }\end{array}$} & 6 & 5 & 32 & 75 & 182 & \multirow[t]{2}{*}{3.83} \\
\hline & & $2.0 \%$ & $1.7 \%$ & $10.6 \%$ & $24.9 \%$ & $60.5 \%$ & \\
\hline \multicolumn{7}{|c|}{ Aggregates } & 3.10 \\
\hline
\end{tabular}

Notes: 1 - Strongly Disagree (SD); 2 - Disagree (D); 3 - Neutral (N); 4 - Agree (A); 5 - Strongly Agree (SA)

Responses on the compliance of Murabahah to the principles of Shari'ah show that the process of the contract under Murabahah does not include uncertainty (Gharar), $81 \%$ agree that there is no uncertainty in the process, on the absence of interest charges, the customers are satisfied that there are no interest charges by $83 \%$, and $85 \%$ agreed that the rulings of Shari'ah are followed in the supply of the items ordered. $12 \%$, $10 \%$, and $11 \%$ were not decided on whether there is uncertainty, interest charging and abidance of Shari'ah in the process of the transaction under Murabahah, while $3 \%, 3 \%$, and $2 \%$ disagree to that effect. The aggregate mean score of 3.10 suggests that customers are moderately satisfied with the compliance of Shari'ah in the process of the transaction in Murabahah contract.

Respondents' level of satisfaction with the perceived quality of Mudarabah is measured by six items coded from DPQ1 to DPQ6 as presented in Table 10.

Table 10 - Respondents level of satisfaction with the perceived quality of Mudarabah

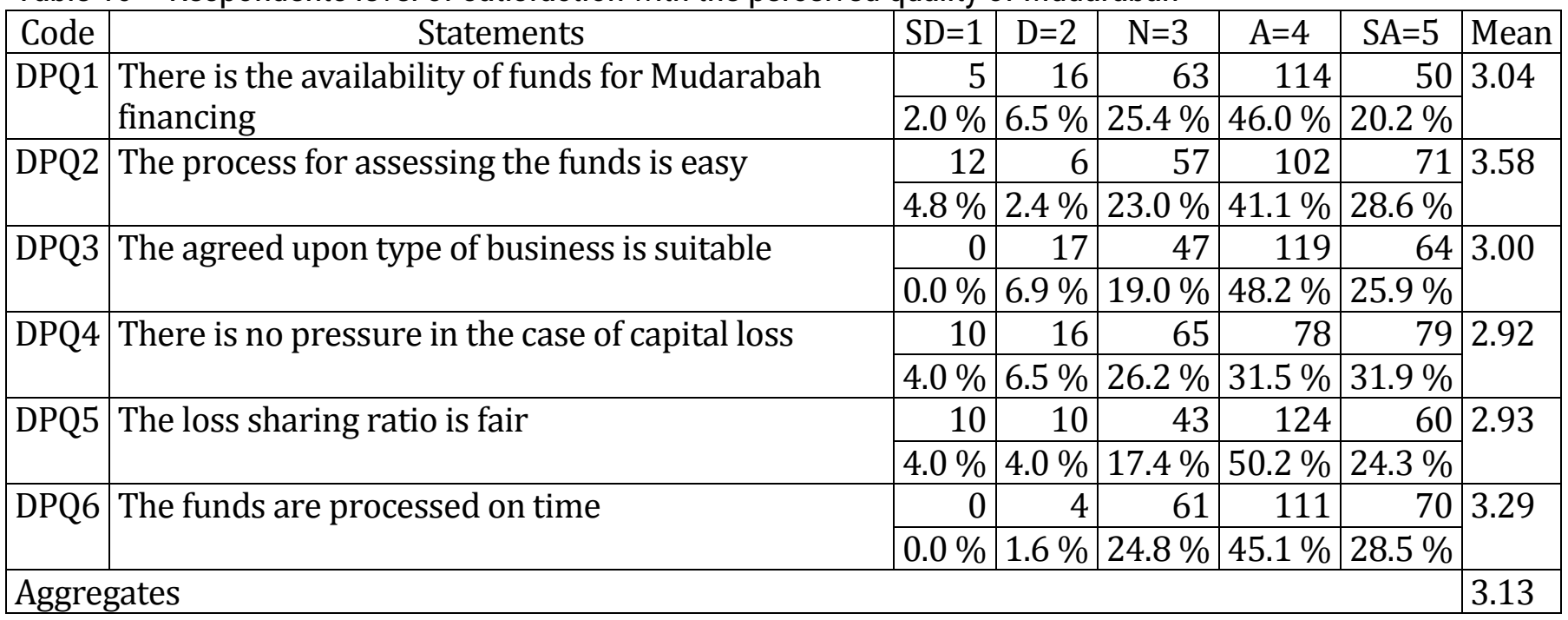

Notes: 1 - Strongly Disagree (SD); 2 - Disagree (D); 3 - Neutral (N); 4 - Agree (A); 5 - Strongly Agree (SA) 
Table 10 revealed the respondents' satisfaction with the perceived quality of Mudarabah. Respondents agree with the availability of funds for Mudarabah financing and easy accessibility to the funds $67 \%$ and $69 \%$ respectively, $25 \%$ and $23 \%$ were not decided while $2 \%$ and $5 \%$ respectively disagree to that effect. On the suitability of the agreed-upon type of business to be carried out, $74 \%$ agreed with the suitability of the type of business agreed-upon, $19 \%$ were undecided, while $7 \%$ disagree. On pressure in case of capital loss, fairness in loss sharing ratio and the time taken to process the money for Mudarabah, customers agreed by $63 \%, 75 \%$, and $76 \%$ respectively, $26 \%, 17 \%$, and $25 \%$ were respectively undecided while $4 \%$ disagree on each of the absence of pressure in case of loss, and fairness loss sharing ratio respectively. The aggregate mean score of the perceived quality of $\mathrm{Mu}$ darabah was found to be moderate among the customers.

Respondents' level of satisfaction with the cost of Mudarabah is measured by four items coded from DC01 to DCO6 as presented in Table 11.

Table 11 - Respondents level of satisfaction with the cost of using Mudarabah

\begin{tabular}{|c|c|c|c|c|c|c|c|}
\hline Code & Statements & $\mathrm{SD}=1$ & $\mathrm{D}=2$ & $\mathrm{~N}=3$ & $A=4$ & $\mathrm{SA}=5$ & Mean \\
\hline \multirow[t]{2}{*}{ DC01 } & \multirow[t]{2}{*}{ The profit sharing ratio is fair } & 0 & 12 & 44 & 134 & 58 & \multirow[t]{2}{*}{4.11} \\
\hline & & $0.0 \%$ & $4.8 \%$ & $17.7 \%$ & $54.0 \%$ & $23.4 \%$ & \\
\hline \multirow[t]{2}{*}{ DCO2 } & \multirow[t]{2}{*}{ The risk involved is high } & 0 & 10 & 68 & 114 & 56 & \multirow[t]{2}{*}{4.01} \\
\hline & & $0.0 \%$ & $4.0 \%$ & $27.4 \%$ & $46.0 \%$ & $22.6 \%$ & \\
\hline \multirow[t]{2}{*}{ DCO3 } & \multirow[t]{2}{*}{ The time allowed for the business is suitable } & 6 & 0 & 46 & 173 & 23 & \multirow[t]{2}{*}{3.93} \\
\hline & & $2.4 \%$ & $0.0 \%$ & $18.5 \%$ & $69.8 \%$ & $9.3 \%$ & \\
\hline \multirow[t]{2}{*}{ DCO4 } & \multirow{2}{*}{ There is no penalty in case of loss } & 0 & 10 & 46 & 111 & 79 & \multirow[t]{2}{*}{4.21} \\
\hline & & $0.0 \%$ & $4.0 \%$ & $18.6 \%$ & $44.9 \%$ & $32.0 \%$ & \\
\hline \multicolumn{7}{|c|}{ Aggregates } & 4.07 \\
\hline
\end{tabular}

Notes: 1 - Strongly Disagree (SD); 2 - Disagree (D); 3 - Neutral (N); 4 - Agree (A); 5 - Strongly Agree (SA)

Table 11 revealed the respondents' satisfaction on the cost chargeable in Mudarabah; the respondents agree that the profit sharing ration being fair, and the involvement of high risk in Mudarabah financing by $77 \%$ and $69 \%$ respectively, $18 \%$ and $27 \%$ were not decided. $78 \%$ agreed that the required maturing time for the business is given by the bank, $19 \%$ were not decided while $2 \%$ disagree. On the penalty in cases of loss, $67 \%$ agreed that the bank does not penalize any partner in case of loss, $17 \%$ unde- cided while $4 \%$ disagree with the statement. The aggregate mean score of 4.01 fall within the region of good/satisfied, which signifies that the customers are satisfied with the cost incurred in using Mudarabah financing contract.

Respondents' level of satisfaction with the convenience in using of Mudarabah is measured by three items coded from DCV1 to DCV3 as presented in Table 12.

Table 12 - Respondents level of satisfaction with the convenience in using Mudarabah

\begin{tabular}{|c|c|c|c|c|c|c|c|}
\hline Code & Statements & $\mathrm{SD}=1$ & $\mathrm{D}=2$ & $\mathrm{~N}=3$ & $A=4$ & $\mathrm{SA}=5$ & Mean \\
\hline \multirow[t]{2}{*}{ DCV1 } & \multirow{2}{*}{$\begin{array}{l}\text { I feel convenient in carrying out the } \\
\text { business activities }\end{array}$} & 5 & 9 & 45 & 121 & 68 & \multirow[t]{2}{*}{4.12} \\
\hline & & $2.0 \%$ & $3.6 \%$ & $18.1 \%$ & $48.8 \%$ & $27.4 \%$ & \\
\hline \multirow[t]{2}{*}{ DCV2 } & \multirow{2}{*}{$\begin{array}{l}\text { There is no restriction on the business } \\
\text { provided it is Shari'ah permissible }\end{array}$} & 4 & 0 & 36 & 123 & 85 & \multirow[t]{2}{*}{3.85} \\
\hline & & $1.6 \%$ & $0.0 \%$ & $14.5 \%$ & $49.6 \%$ & $34.3 \%$ & \\
\hline \multirow[t]{2}{*}{ DCV3 } & \multirow{2}{*}{$\begin{array}{l}\text { I am convenient with the type of business } \\
\text { agreed upon }\end{array}$} & 0 & 4 & 48 & 119 & 76 & \multirow[t]{2}{*}{3.73} \\
\hline & & $0.0 \%$ & $1.6 \%$ & $19.4 \%$ & $48.2 \%$ & $30.8 \%$ & \\
\hline \multicolumn{7}{|c|}{ Aggregates } & 3.90 \\
\hline
\end{tabular}

Notes: 1 - Strongly Disagree (SD); 2 - Disagree (D); 3 - Neutral (N); 4 - Agree (A); 5 - Strongly Agree (SA) 
Responses on the convenience of the customers in using Mudarabah indicate that $76 \%$ agree that they feel convenient in carrying out businesses under Mudarabah financing, $18 \%$ were not decided while $6 \%$ disagree, on restriction on the business coverage $84 \%$ agreed that they are allowed to carry out the business everywhere without any restriction, $15 \%$ were not decided while $25 \%$ disagree. The type of business agreed on; users also agreed they are convenient with it by $80 \%, 19 \%$ were undecided, while $2 \%$ disagree. And the aggregate mean score of 3.90 also determines that they are satisfied with conveniences in using Mudarabah financing.

Respondents' level of satisfaction with the compliance of Mudarabah is measured by three items coded from DCP1 to DCP3 as presented in Table 13.

Table 13 - Respondents level of satisfaction with compliance of Mudarabah

\begin{tabular}{|c|c|c|c|c|c|c|c|}
\hline Code & Statements & $\mathrm{SD}=1$ & $\mathrm{D}=2$ & $\mathrm{~N}=3$ & $A=4$ & $\mathrm{SA}=5$ & Mean \\
\hline \multirow[t]{2}{*}{ DCP1 } & \multirow[t]{2}{*}{ There is no interest charged on the funds } & 0 & 0 & 63 & 126 & 59 & \multirow[t]{2}{*}{3.68} \\
\hline & & $0.0 \%$ & $0.0 \%$ & $25.4 \%$ & $50.8 \%$ & $23.8 \%$ & \\
\hline \multirow[t]{2}{*}{ DCP2 } & \multirow{2}{*}{$\begin{array}{l}\text { There is no gambling neither any nonhalal busi- } \\
\text { ness }\end{array}$} & 0 & 5 & 56 & 118 & 69 & \multirow[t]{2}{*}{3.82} \\
\hline & & $0.0 \%$ & $2.0 \%$ & $22.6 \%$ & $47.6 \%$ & $27.8 \%$ & \\
\hline \multirow[t]{2}{*}{ DCP3 } & \multirow[t]{2}{*}{ The process is shari'ah compliant } & 0 & 3 & 32 & 103 & 110 & \multirow[t]{2}{*}{3.90} \\
\hline & & $0.0 \%$ & $1.2 \%$ & $12.9 \%$ & $41.5 \%$ & $44.4 \%$ & \\
\hline \multicolumn{7}{|c|}{ AGGREGATES } & 3.80 \\
\hline
\end{tabular}

Notes: 1 - Strongly Disagree (SD); 2 - Disagree (D); 3 - Neutral (N); 4 - Agree (A); 5 - Strongly Agree (SA)

Responses on the compliance of Wadi'ah account to the principles of Shari'ah show that the process of the transaction on the account, the absence of interest charges and engaging money in nonShari'ah compliant businesses, customers are satisfied that the dictates of Shari'ah are followed with $59 \%, 62 \%$, and $65 \%$ respectively. $32 \%$, $31 \%$, and $27 \%$ were not decided on whether there is compliant of Shari'ah in the process of the transaction with Wadi'ah account, while $8 \%$, $6 \%$, and $7 \%$ disagree to that effect. The aggregate mean score of 3.52 suggests that customers are satisfied with the compliance of Shari'ah in the process of the transaction on Mudarabah financing.

\section{Convergent Validity and Reliability}

The assessment of the Convergent validity was done using the factor loadings, $t$ - statistics, Average Variance Extracted (AVE) and composite reliability. When the factor loadings are found to be high and statistically significant, then the Convergent validity is said to have been achieved. Author [81], asserted that a t-statistic value above 1.96 indicates a significant outer loading. Average Variance Extracted (AVE) is recommended to be above 0.5 , while composite reliability is recommended to be above 0.6. The use of Average Variance Extracted (AVE) to measure the convergent validity ensures that each measurement model measures what it should measure. It also shows that the constructs are free from measurement errors. It shows that the items in the construct are valid and reliable which ensure the accuracy of the research findings.

Table 14 is the outer model of the perceived quality of Murabahah towards customer satisfaction construct presenting the factor loadings, tstatistics, Average Variance Extracted (AVE) and composite reliability.

Table 14 - The outer model of perceived quality of Murabahah towards customer satisfaction

\begin{tabular}{|l|c|c|c|c|}
\hline Items & $\begin{array}{c}\text { Factor } \\
\text { Loadings }\end{array}$ & T-value & $\begin{array}{c}\text { Average } \\
\text { Variance } \\
\text { Extracted } \\
\text { (AVE) }\end{array}$ & $\begin{array}{c}\text { Composite } \\
\text { Reliability } \\
\text { (C.R.) }\end{array}$ \\
\hline MPQ1 & 0.732 & $12.578^{* *}$ & & \\
MPQ2 & 0.919 & $62.628^{* *}$ & 0.597 & 0.853 \\
MPQ3 & 0.654 & $10.194^{* *}$ & & \\
MPQ4 & 0.760 & $14.363^{* *}$ & & \\
\hline
\end{tabular}

Notes: significant level ${ }^{\star *} \mathrm{p}<0.05$

The entire items factor loadings, ranging from 0.654 to 0.919 were significant at 0.001 level, with t-statistics value ranges from 10.194 to 
62.628 above the lowest threshold of 1.96 . The AVE was 0.597 above the recommended 0.5 thresholds. This means that the estimation is good. The composite reliability (C.R.) value was 0.853 above the recommended 0.6 , signifying the high internal consistency of the outer (measurement) model. Therefore, the convergent validity and reliability were confirmed.

Table 15 is the outer model of the cost of Murabahah towards customer satisfaction construct presenting the factor loadings, t-statistics, Average Variance Extracted (AVE) and composite reliability.

Table 15 - An outer model of Murabahah cost towards customer satisfaction

\begin{tabular}{|l|l|c|c|c|}
\hline Items & $\begin{array}{c}\text { Factor } \\
\text { Loadings }\end{array}$ & T-value & $\begin{array}{c}\text { Average } \\
\text { Variance } \\
\text { Extracted } \\
\text { (AVE) }\end{array}$ & $\begin{array}{c}\text { Composite } \\
\text { Reliability } \\
\text { (C.R.) }\end{array}$ \\
\hline MC01 & 0.633 & $10.366^{* *}$ & & \\
MC02 & 0.805 & $22.982^{* *}$ & 0.671 & 0.889 \\
MC03 & 0.909 & $41.242^{* *}$ & & \\
MC04 & 0.900 & $35.792^{* *}$ & & \\
\hline
\end{tabular}

Notes: significant level ${ }^{\star *} \mathrm{p}<0.05$

The entire items factor loadings, ranging from 0.633 to 0.909 were significant at 0.001 level, with t-statistics value ranges from 10.366 to 41.242 above the lowest threshold of 1.96. The AVE was 0.671 above the recommended 0.5 thresholds. Thus, the estimation is good. The composite reliability (C.R.) value was 0.889 above the recommended 0.6 , signifying the high internal consistency of the outer (measurement) model. Therefore, the convergent validity and reliability were confirmed.

Table 16 is the outer model of the convenience in Murabahah towards customer satisfaction construct presenting the factor loadings, t-statistics, Average Variance Extracted (AVE) and composite reliability.

The entire items factor loadings, ranging from 0.323 to 0.947 were significant at 0.001 level, with t-statistics value ranges from 1.984 to 147.099 above the lowest threshold of 1.96. The AVE was 0.624 above the recommended 0.5 thresholds. And the estimation was found to be good. The composite reliability (C.R.) value was 0.811 above the recommended 0.6 , signifying the high internal consistency of the outer (measurement) model. Therefore, the convergent validity and reliability were confirmed.

Table 16 - An outer model of the cost of Murabahah convenience towards customer satisfaction

\begin{tabular}{|c|c|c|c|c|}
\hline Items & $\begin{array}{c}\text { Factor } \\
\text { Loadings }\end{array}$ & T-value & $\begin{array}{c}\text { Average } \\
\text { Variance } \\
\text { Extracted } \\
\text { (AVE) }\end{array}$ & $\begin{array}{c}\text { Composite } \\
\text { Reliability } \\
\text { (C.R.) }\end{array}$ \\
\hline MCV1 & 0.933 & $37.655^{* *}$ & & \\
\hline MCV2 & 0.947 & $147.099 * *$ & 0.624 & 0.811 \\
\hline MCV3 & 0.323 & $1.984^{* *}$ & & \\
\hline
\end{tabular}

Notes: significant level ${ }^{\star \star} p<0.05$

Table 17 is the outer model of the compliance of Murabahah towards customer satisfaction construct presenting the factor loadings, t-statistics, Average Variance Extracted (AVE) and composite reliability.

Table 17 - An outer model of the cost of Murabahah compliance towards customer satisfaction

\begin{tabular}{|c|c|c|c|c|}
\hline Items & $\begin{array}{l}\text { Factor } \\
\text { Loadings }\end{array}$ & $\mathrm{T}$-value & $\begin{array}{c}\text { Average } \\
\text { Variance } \\
\text { Extracted } \\
\text { (AVE) }\end{array}$ & $\begin{array}{l}\text { Composite } \\
\text { Reliability } \\
\text { (C.R.) }\end{array}$ \\
\hline $\begin{array}{l}\text { MCP1 } \\
\text { MCP2 } \\
\text { MCP3 }\end{array}$ & $\begin{array}{l}0.576 \\
0.923 \\
0.765\end{array}$ & \begin{tabular}{|l|}
$2.838^{* *}$ \\
$69.419^{* *}$ \\
$9.869^{* *}$
\end{tabular} & 0.590 & 0.806 \\
\hline
\end{tabular}

Notes: significant level ${ }^{\star \star} p<0.05$

The entire items factor loadings, ranging from 0.576 to 0.923 were significant at 0.001 level, with t-statistics value ranges from 2.838 to 69.419 above the lowest threshold of 1.96 . The AVE was 0.590 above the recommended 0.5 thresholds. Thus, the estimation is good. The composite reliability (C.R.) value was 0.806 above the recommended 0.6 , signifying the high internal consistency of the outer (measurement) model. Therefore, the convergent validity and reliability were confirmed.

Table 18 is the outer model of Mudarabah perceived quality towards customer satisfaction construct presenting the factor loadings, tstatistics, Average Variance Extracted (AVE) and composite reliability.

The entire items factor loadings, ranging from 0.613 to 0.987 were significant at 0.001 level, 
with t-statistics value ranges from 13.321 to 354.364 above the lowest threshold of 1.96. The AVE was 0.808 above the recommended 0.5 thresholds. Thus, the estimation is good.

Table 18 - An outer model of Mudarabah perceived quality towards customer satisfaction

\begin{tabular}{|l|l|l|c|c|}
\hline Items & $\begin{array}{c}\text { Factor } \\
\text { Loadings }\end{array}$ & T-value & $\begin{array}{c}\text { Average } \\
\text { Variance } \\
\text { Extracted } \\
\text { (AVE) }\end{array}$ & $\begin{array}{c}\text { Composite } \\
\text { Reliability } \\
\text { (C.R.) }\end{array}$ \\
\hline DPQ1 & 0.987 & $354.364^{* *}$ & & \\
DPQ2 & 0.788 & $37.161^{* *}$ & & \\
DPQ3 & 0.613 & $13.321^{* *}$ & 0.808 & 0.961 \\
DPQ4 & 0.980 & $214.724^{* *}$ & & \\
DPQ5 & 0.976 & $124.621^{* *}$ & & \\
DPQ6 & 0.982 & $244.093^{* *}$ & & \\
\hline
\end{tabular}

Notes: significant level ${ }^{\star *} \mathrm{p}<0.05$

The composite reliability (C.R.) value was 0.961 above the recommended 0.6 , signifying the high internal consistency of the outer (measurement) model. Therefore, the convergent validity and reliability were confirmed.

Table 19 is the outer model of the cost of Mudarabah towards customer satisfaction construct presenting the factor loadings, t-statistics, Average Variance Extracted (AVE) and composite reliability.

Table 19 - An outer model of the cost of Mudarabah towards customer satisfaction

\begin{tabular}{|l|l|c|c|c|}
\hline Items & $\begin{array}{c}\text { Factor } \\
\text { Loadings }\end{array}$ & T-value & $\begin{array}{c}\text { Average } \\
\text { Variance } \\
\text { Extracted } \\
\text { (AVE) }\end{array}$ & $\begin{array}{c}\text { Composite } \\
\text { Reliability } \\
\text { (C.R.) }\end{array}$ \\
\hline DC01 & 0.766 & $17.315^{* *}$ & & \\
DC02 & 0.693 & $13.046^{* *}$ & 0.589 & 0.851 \\
DC03 & 0.801 & $17.962^{* *}$ & & \\
DC04 & 0.804 & $26.302^{* *}$ & & \\
\hline
\end{tabular}

Notes: significant level ${ }^{\star *} p<0.05$

The entire items factor loadings, ranging from 0.693 to 0.804 were significant at 0.001 level, with t-statistics value ranges from 13.046 to 26.302 above the lowest threshold of 1.96. The AVE was 0.589 above the recommended 0.5 thresholds. Thus, the estimation is good. The composite reliability (C.R.) value was 0.851 above the recommended 0.6 , signifying the high internal consistency of the outer (measurement) model. Therefore, the convergent validity and reliability were confirmed.

Table 20 is the outer model of Mudarabah convenience towards customer satisfaction construct presenting the factor loadings, t-statistics, Average Variance Extracted (AVE) and composite reliability.

Table 20 - An outer model of Mudarabah convenience towards customer satisfaction

\begin{tabular}{|c|c|c|c|c|}
\hline Items & $\begin{array}{c}\text { Factor } \\
\text { Loadings }\end{array}$ & T-value & $\begin{array}{c}\text { Average } \\
\text { Variance } \\
\text { Extracted } \\
\text { (AVE) }\end{array}$ & $\begin{array}{c}\text { Composite } \\
\text { Reliability } \\
\text { (C.R) }\end{array}$ \\
\hline DCV1 & 0.927 & $47.164^{* *}$ & \multirow{3}{*}{0.684} & \multirow{3}{*}{0.866} \\
\hline DCV2 & 0.817 & $27.399 * *$ & & \\
\hline DCV3 & 0.726 & $15.607^{* *}$ & & \\
\hline
\end{tabular}

Notes: significant level ${ }^{\star *} p<0.05$

The entire items factor loadings, ranging from 0.726 to 0.927 were significant at 0.001 level, with t-statistics value ranges from 15.607 to 47.164 above the lowest threshold of 1.96. The AVE was 0.684 above the recommended 0.5 thresholds. Thus, the estimation is good. The composite reliability (C.R.) value was 0.866 above the recommended 0.6 , signifying the high internal consistency of the outer (measurement) model. Therefore, the convergent validity and reliability were confirmed.

Table 21 is the outer model of Mudarabah compliance towards customer satisfaction construct presenting the factor loadings, t-statistics, Average Variance Extracted (AVE) and composite reliability.

Table 21 - An outer model of Mudarabah compliance towards customer satisfaction

\begin{tabular}{|l|l|l|c|c|}
\hline Items & $\begin{array}{c}\text { Factor } \\
\text { Loadings }\end{array}$ & T-value & $\begin{array}{c}\text { Average } \\
\text { Variance } \\
\text { Extracted } \\
\text { (AVE) }\end{array}$ & $\begin{array}{c}\text { Composite } \\
\text { Reliability } \\
\text { (C.R.) }\end{array}$ \\
\hline DCP1 & 0.710 & $6.762^{* *}$ & & \\
DCP2 & 0.658 & $5.689^{* *}$ & 0.516 & 0.761 \\
DCP3 & 0.782 & $7.868 * *$ & & \\
\hline
\end{tabular}

Notes: significant level ${ }^{\star \star} p<0.05$

The entire items factor loadings, ranging from 0.658 to 0.782 were significant at 0.001 level, with t-statistics value ranges from 5.689 to 7.868 above the lowest threshold of 1.96. The AVE was 0.516 above the recommended 0.5 threshold, 
which signifies that the estimation is good. The composite reliability (C.R.) value was 0.761 above the recommended 0.6 , signifying the high internal consistency of the outer (measurement) model. Therefore, the convergent validity and reliability were confirmed.

Table 22 is the outer model of the customer satisfaction construct presenting the factor loadings, t-statistics, Average Variance Extracted (AVE) and composite reliability.

Table 22 - An outer model of customer satisfaction

\begin{tabular}{|l|l|l|c|c|}
\hline Items & $\begin{array}{c}\text { Factor } \\
\text { Loadings }\end{array}$ & T-value & $\begin{array}{c}\text { Average } \\
\text { Variance } \\
\text { Extracted } \\
\text { (AVE) }\end{array}$ & $\begin{array}{c}\text { Composite } \\
\text { Reliability } \\
\text { (C.R.) }\end{array}$ \\
\hline CS4 & 0.878 & $48.779^{* *}$ & & \\
CS5 & 0.600 & $16.276^{* *}$ & & \\
CS6 & 0.755 & $32.015^{* *}$ & 0.711 & 0.960 \\
CS7 & 0.890 & $43.639^{* *}$ & & \\
CS8 & 0.876 & $48.002^{* *}$ & & \\
CS9 & 0.885 & $42.980^{* *}$ & & \\
\hline
\end{tabular}

Notes: significant level ${ }^{\star *} p<0.05$
The entire items factor loadings, ranging from 0.600 to 0.890 were significant at 0.001 level, with t-statistics value ranges from 16.276 to 48.779 above the lowest threshold of 1.96 . The AVE was 0.711 above the recommended 0.5 thresholds. Thus, the estimation is good. The composite reliability (C.R.) value was 0.960 above the recommended 0.6 , signifying the high internal consistency of the outer (measurement) model. Therefore, the convergent validity and reliability were confirmed.

\section{Inner (structural) Model of Murabahah}

The inner (structural) model was modelled using the PLS interface. The outer models, comprising the exogenous latent constructs of $\mathrm{PQ}, \mathrm{CO}, \mathrm{CV}$ and $\mathrm{CP}$ for Murabahah, as well as the endogenous construct of CS, were connected by path arrows pointing the dependent construct to form the structural model. The result of the structural model is depicted in Figure 1.

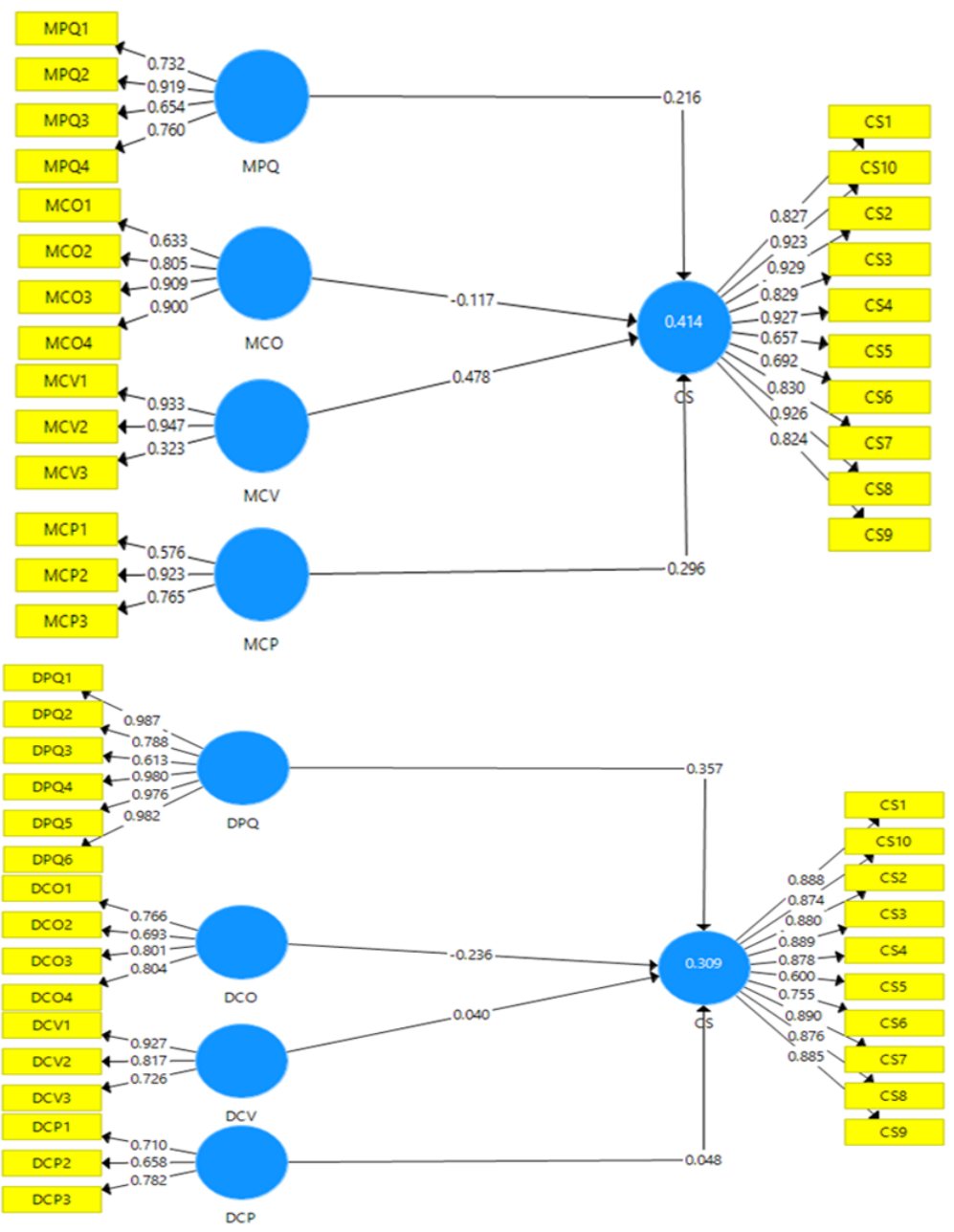

Figure 1 - Inner (structural) Model of Murabahah 
The result model shows an $\mathrm{R}^{2}$ value of 0.414 which means $41 \%$ of the variance of customer satisfaction is explained by the exogenous constructs of perceived quality, cost, convenience and compliance of Murabahah. The 0.414 value of $\mathrm{R}^{2}$ is moderate above the recommended value of 0.33 according to [22]. The constructs were found to be moderate in determining the satisfaction of customers as they produced $\mathrm{R}^{2}$ of 0.414 as shown in Figure 1.

The result model shows an $\mathrm{R}^{2}$ value of 0.309 which means $30 \%$ of the variance of customer satisfaction is explained by the exogenous constructs of perceived quality, cost, convenience and compliance of Mudarabah. The 0.309 value of $\mathrm{R}^{2}$ is substantially above the recommended value of 0.26 according to [22]. The constructs were found to be moderate in determining the satisfaction of customers as they produced $\mathrm{R}^{2}$ of 0.309 as shown in Figure 1.

Perceived quality towards customer satisfaction. The research found a correlation relationship between the perceived quality of the products and customer satisfaction with (t-statistics $=4.943$ and path weight of 0.313 ), and the p-value of 0.000 which implies that the hypothesis (H1) is accepted as the perceived quality of Islamic bank products significantly affect customer satisfaction and this finding is similar to that of [19], where they found that perceived quality of green products has a positive effect on customer satisfaction, and also [38] saw the same direct and positive relationship between product perceived quality and customer satisfaction in hotel industry. Though, a score of findings found a negative and indirect relationship between perceived quality of products and customer satisfaction, for instance in the findings of [58].

Cost towards customer satisfaction. The research findings in this study indicate that the cost of using the products has a significant effect on customer satisfaction (with t-statistic $=1.990$ and regression weight $=0.121$ ), which is in support of hypothesis (H2). This result is similar with the findings of [21], in which they reported that cost of online banking has a significant and positive effect on customer satisfaction. The result of this study implies that cost influences customer satisfaction of Islamic banking products. And this notion is also consistent with the findings [19] in which they stressed that customers do determine the level of cost as one of the major concern is attaining their satisfaction on using services of banks.
Convenience towards customer satisfaction. As hypothesized in the study, the convenience to have a positive effect on customer satisfaction, and the causal effect of convenience and customer satisfaction is significant as it has the tstatistic at 5.303 with regression weight $=0.370$, and this finding consistent the finding of [35], who found that the convenience of online banking has a significant and positive effect on customer satisfaction.

Compliance towards customer satisfaction. Compliance was found to affect customer satisfaction positively as hypothesized by (H4), the result shows a t-value of 3.079 and path weight of 0.195 , and $p$-value of 0.002 which indicates the hypothesis been accepted, and this finding tallies with the findings of [4] where they found compliance with the religion as the most significant attribute that contributes to customer satisfaction. Also, [9] confirm this result by finding religion as the highest significant factor in making a selection of a bank by customers. Though [14] found an insignificant relationship between compliance and customer satisfaction in Islamic banking in Nigeria.

\section{CONCLUSION}

Customer satisfaction has been established to be the priority of any commercial bank. However, this is hardly achieved all over due to many problems ranging from changes in taste of the customers, pressures from competitors, the perception of the customers with regards to the products and services rendered by the banks, the quality of the products and services and so on.

This study investigated the effects of Islamic bank products features in relation to customer satisfaction. The satisfaction of the customers on the perceived quality of the products, cost of using the products, convenient as observed by the customers and the compliance of the products with Shari'ah were studied. The research hypotheses were tested in the survey within the context of customers of Ja'iz Islamic bank of Nigeria.

The findings show a higher level of satisfaction was achieved on cost, convenience, and compliance of the products to Shari'ah principles, while a moderate level of satisfaction with the perceived quality of the products was attained as responded by the customers. Hence, there is a need for the bank policymakers to engage in im- 
proving the quality of the products to enable them to retain their existing customers and lure other potential customers toward patronizing their products and services.

Finally, banks will manage to remain the essential financial institutions in the industry only if they will be quick in attempting to solving customers problems and providing the customers with their expected or exceed the customers' expectation to avoid switching of customers from one bank to another competitor. Essentially, a comprehensive and well-managed customer satisfaction attainment is never an optional phenomenon but a surviving tool for banks in both the short and long run [8].

\section{REFERENCES}

1. Ahmad, A., Rehman, K., \& Safwan, N. (2011). Comparative study of Islamic and conventional banking in Pakistan based on customer satisfaction. African Journal of Business Management, 5(5), 17681773.

2. Ahmad, A., Rehman, K., Saif, I., \& Safwan, N. (2010). An empirical investigation of Islamic banking in Pakistan based on perception of service quality. African Journal of Business Management, 4(6), 1185-1193.

3. Ahmed, H. (2009). The financial crisis: risks and lessons for Islamic finance. ISRA International Journal of Islamic Finance, 1(1), 7-32.

4. Al-Deehani, T., EL-Sadi, H., \& Al-Deehani, M. (2015). The performance of Islamic banks and conventional banks before and during the economic downturn. Investment Management and Financial Innovation, 12(2), 238-250.

5. Aldoseri, M., \& Worthington, A. C. (2016). Risk Management in Islamic Banking: An Emerging Market Imperative. In Risk Management in Emerging Markets (pp. 229-252). doi: 10.1108/978-178635-452-520161020

6. Amin, H., Abdul Rahman, A. R., Abdul Razak, D., \& Rizal, H. (2017). Consumer attitude and preference in the Islamic mortgage sector: a study of Malaysian consumers. Management Research Review, 40(1), 95-115. doi: 10.1108/mrr-07-2015-0159

7. Anderson, E. W., Fornell, C., \& Lehmann, D. R. (1994). Customer Satisfaction, Market Share, and Profitability: Findings from Sweden. Journal of Marketing, 58(3), 53. doi: 10.2307/1252310

8. Aquilani, B., Silvestri, C., Ruggieri, A., \& Gatti, C. (2017). A systematic literature review on total quality management critical success factors and the identification of new avenues of research. The TQM Journal, 29(1), 184-213. doi: 10.1108/TQM-01-2016-0003

9. Askari, H., Iqbal, Z., \& Mirakhor, A. (2011). New Issues in Islamic Finance and Economics: Progress and Challenges. Hoboken: John Wiley \& Sons.

10. Idris, A. R., Asari, F. F., Taufik, N. A., Salim, N. J., Mustaffa, R., \& Jusoff, K. (2011). Determinant of Islamic banking institutions' profitability in Malaysia. World Applied Science Journal, 12, 1-7.

11. Pervez, A. (2012). Principles of Islamic interest free banking in Pakistan : study foucsing on three Islamic banks in Pakistan. Saarbrücken: Lambert academic Publishing.

12. Bansal, H. S., \& Taylor, S. (2014). Investigating the Relationship Between Service Quality, Satisfaction and Switching Intentions. Proceedings of the 1997 Academy of Marketing Science (AMS) Annual Conference, 304-313. doi: 10.1007/978-3-319-13141-2_107

13. Bello, A., \& Abubakar, M. (2014). Challenges and Solutions to Islamic Banking System in a Pluralistic-Secular Country like Nigeria. Mediterranean Journal of Social Sciences, 5(6), 25-34. doi: 10.5901/mjss.2014.v5n6p25 
14. Ben Selma Mokni, R., \& Rachdi, H. (2014). Assessing the bank profitability in the MENA region. International Journal of Islamic and Middle Eastern Finance and Management, 7(3), 305-332. doi: 10.1108/imefm-03-2013-0031

15. Blut, M., Beatty, S. E., Evanschitzky, H., \& Brock, C. (2014). The Impact of Service Characteristics on the Switching Costs-Customer Loyalty Link. Journal of Retailing, 90(2), 275-290. doi: 10.1016/j.jretai.2014.04.003

16. Boohene, R., Agyapong, G. K. Q., \& Gonu, E. (2013). Factors Influencing the Retention of Customers of Ghana Commercial Bank within the Agona Swedru Municipality. International Journal of Marketing Studies, 5(4). doi: 10.5539/ijms.v5n4p82

17. Bouranta, N., Psomas, E. L., \& Pantouvakis, A. (2017). Identifying the critical determinants of TQM and their impact on company performance. The TQM Journal, 29(1), 147-166. doi: 10.1108/tqm11-2015-0142

18. Chang, C.-S., Chen, S.-Y., \& Lan, Y.-T. (2013). Service quality, trust, and patient satisfaction in interpersonal-based medical service encounters. BMC Health Services Research, 13(1). doi: 10.1186/1472-6963-13-22

19. Chatzoglou, P., Chatzoudes, D., \& Kipraios, N. (2015). The impact of ISO 9000 certification on firms' financial performance. International Journal of Operations \& Production Management, 35(1), 145-174. doi: 10.1108/ijopm-07-2012-0387

20. Cheah, C. M., Teo, A. C., Sim, J. J., Oon, K. H., \& Tan, B. I. (2011). Factors affecting Malaysian mobile banking adoption: an empirical analysis. International Journal of Network and Mobile Technologies, 2(3), 149-160.

21. Chin, W. W. (1998). Commentary: Issues and opinion on structural equation modeling. MIS Quarterly, 22(1), 7-16.

22. Chu, H.-C., \& Chu, K.-M. (2007). The construction model of customer trust, perceived value and customer loyalty. Review of Business Research, 7(1), 107.

23. Čihák, M., \& Hesse, H. (2010). Islamic Banks and Financial Stability: An Empirical Analysis. Journal of Financial Services Research, 38(2-3), 95-113. doi: 10.1007/s10693-010-0089-0

24. Coetzee, J., Van Zyl, H., \& Tait, M. (2013). Perceptions of service quality by clients and contactpersonnel in the South African retail banking sector. Southern African Business Review, 17(1), 122.

25. Corbett, C., \& Van Wassenhove, L. (1993). Trade-offs? What trade-offs? Competence and competitiveness in manufacturing strategy. Retrieved from https://pdfs.semanticscholar.org/1706/45716cd7b23629bd8a94624955b4ea79000c.pdf?_ga= 2.41375648.36989901.1546773518-591376057.1546164660

26. De Vita, L., Mari, M., \& Poggesi, S. (2014). Women entrepreneurs in and from developing countries: Evidences from the literature. European Management Journal, 32(3), 451-460. doi: 10.1016/j.emj.2013.07.009

27. Dey, P. K., Bhattacharya, A., Ho, W., \& Clegg, B. (2015). Strategic supplier performance evaluation: A case-based action research of a UK manufacturing organisation. International Journal of Production Economics, 166, 192-214. doi: 10.1016/j.ijpe.2014.09.021

28. Donner, F. M. (2014). The early Islamic conquests. New Jersey: Princeton University Press.

29. Driscoll, D. L. (2011). Introduction to Primary Research: Observations, Surveys, and Interviews. Retrieved from https://wac.colostate.edu/books/writingspaces2/driscoll--introduction-toprimary-research.pdf

30. Duran, J. J., \& Garcia-Lopez, M.-J. (2012). The Internationalization of Islamic Banking and Finance: The Co-Evolution of Institutional Changes and Financial Services Integration. International Journal of Business and Management, 7(13), 49-74. doi: 10.5539/ijbm.v7n13p49 
31. Erol, C., \& El-Bdour, R. (1989). Attitudes, Behaviour, and Patronage Factors of Bank Customers towards Islamic Banks. International Journal of Bank Marketing, 7(6), 31-37. doi:

10.1108/02652328910132060

32. Erol, C., Kaynak, E., \& Radi, E. (1990). Conventional and Islamic Banks: Patronage Behaviour of Jordanian Customers. International Journal of Bank Marketing, 8(4), 25-35. doi: 10.1108/02652329010004231

33. Field, A., Miles, J., \& Field, Z. (2012). Discovering statistics using R. London: Sage publications.

34. Flynn, B. B., \& Flynn, E. J. (2005). Synergies between supply chain management and quality management: emerging implications. International Journal of Production Research, 43(16), 34213436. doi: 10.1080/0020754050011807

35. Gallarza, M. G., Arteaga, F., Del Chiappa, G., Gil-Saura, I., \& Holbrook, M. B. (2017). A multidimensional service-value scale based on Holbrook's typology of customer value. Journal of Service Management, 28(4), 724-762. doi: 10.1108/josm-06-2016-0166

36. Garvin, D. A. (1993). Manufacturing Strategic Planning. California Management Review, 35(4), 85106. doi: $10.2307 / 41166756$

37. Ghoshal, S., \& Bartlett, C. A. (1994). Linking organizational context and managerial action: The dimensions of quality of management. Strategic Management Journal, 15(S2), 91-112.

38. Greenland, S. J., Combe, I. A., \& Farrell, A. M. (2016). Stakeholder Preference and Stated vs Derived Importance Satisfaction Research. International Journal of Market Research, 58(1), 35-55. doi: 10.2501/ijmr-2016-005

39. Haron, S. \& Ahmad, N. (2000). The effects of conventional interest rates and rate of profit on funds deposited with Islamic banking system in Malaysia. International Journal of Islamic Financial Services, 1(4).

40. Iheduru, O. C. (2004). Black Economic Power and Nation-Building in Post-Apartheid South Africa. The Journal of Modern African Studies, 42(1), 1-30.

41. Imam, P. A., \& Kpodar, K. (2010, August). Islamic banking: how has it diffused? Retrieved from https://www.imf.org/ /media/Websites/IMF/imported-full-textpdf/external/pubs/ft/wp/2010/_wp10195.ashx

42. Iqbal, M., \& Molyneux, P. (2006). Thirty years of Islamic banking: History, performance and prospects. London, UK: Palgrave Macmillan.

43. Jamal, A., \& Naser, K. (2003). Factors influencing customer satisfaction in the retail banking sector in Pakistan. International Journal of Commerce and Management, 13(2), 29-53. doi: 10.1108/eb047465

44. Ahmad, J., A. \& Majid, M. A. (2012). Benchmarking of financial solutions offered by Islamic banks. Blekinge: Tekniska.

45. Kandampully, J., Zhang, T., \& Bilgihan, A. (2015). Customer loyalty: a review and future directions with a special focus on the hospitality industry. International Journal of Contemporary Hospitality Management, 27(3), 379-414. doi: 10.1108/ijchm-03-2014-0151

46. Karim, R., \& Chowdhury, A. T. (2014). Customer satisfaction on service quality in private commercial banking sector in Bangladesh. British Journal of Marketing Studies, 2(2), 1-11.

47. Johnson, K. (2013). The role of Islamic banking in economic growth. Retrieved from https://scholarship.claremont.edu/cgi/viewcontent.cgi?referer=https://www.google.com/\&htt psredir $=1 \&$ article $=1618 \&$ context $=$ cmc_theses

48. Keiningham, T., Gupta, S., Aksoy, L., \& Buoye, A. (2014). The high price of customer satisfaction. MIT Sloan Management Review, 55(3), 37-46.

49. Keller, S., Korkmaz, G., Orr, M., Schroeder, A., \& Shipp, S. (2017). The Evolution of Data Quality: Understanding the Transdisciplinary Origins of Data Quality Concepts and Approaches. Annual 
Review of Statistics and Its Application, 4(1), 85-108. doi: 10.1146/annurev-statistics-060116054114

50. Kidwell, D. S., Blackwell, D. W., Sias, R. W., \& Whidbee, D. A. (2016). Financial institutions, markets, and money. Hoboken, NJ: John Wiley \& Sons.

51. Klyuvak, O., \& Skrynkovskyy, R. (2018). Diagnostics and Minimization of Business Risks and the State Customer in the System of Public e-Procurement. Path of Science, 4(1), 1022-1032. doi: $10.22178 /$ pos.30-4

52. Marakanon, L., \& Panjakajornsak, V. (2017). Perceived quality, perceived risk and customer trust affecting customer loyalty of environmentally friendly electronics products. Kasetsart Journal of Social Sciences, 38(1), 24-30. doi: 10.1016/j.kjss.2016.08.012

53. Lee, H. L., \& Chin, K. S. (2017). Development of a Systematic Model for Improving Software Quality in the Financial Service Organization. In Management Challenges in a Network Economy: Proceedings of the MakeLearn and TIIM International Conference 2017. Poland: ToKnowPress.

54. Leroi-Werelds, S., Streukens, S., Brady, M. K., \& Swinnen, G. (2013). Assessing the value of commonly used methods for measuring customer value: a multi-setting empirical study. Journal of the Academy of Marketing Science, 42(4), 430-451. doi: 10.1007/s11747-013-0363-4

55. Levine, R. (1998). The Legal Environment, Banks, and Long-Run Economic Growth. Journal of Money, Credit and Banking, 30(3), 596. doi: 10.2307/2601259

56. Lin, J., Hsiao, C.-T., Glen, R., Pai, J.-Y., \& Zeng, S.-H. (2012). Perceived service quality, perceived value, overall satisfaction and happiness of outlook for long-term care institution residents. Health Expectations, 17(3), 311-320. doi: 10.1111/j.1369-7625.2012.00769.x

57. Mittal, S., Gera, R., \& Batra, D. K. (2015). An evaluation of an integrated perspective of perceived service quality for retail banking services in India. International Journal of Bank Marketing, 33(3), 330-350. doi: 10.1108/ijbm-02-2014-0020

58. Moak, K. (2017). Developed Nations and the Economic Impact of Globalization. doi: 10.1007/978-3319-57903-0

59. Moenardy, K. K., Arifin, S. Z., \& Kumadji, S. (2016). The Effect of Service Quality and Relationship Marketing to Customer Value, Customer Satisfaction, Switching Cost, and Customer Retention: A Case Study on the Customers of Bank NTT at East Nusa Tenggara Province. International Journal of Management and Administrative Sciences, 3(4), 48-63.

60. Mohammed, M. I., Sulaiman, N., \& Adamu, D. (2018). Dimensionality and Reliability of the Determinants of Reverse Mortgage Use Intention. Path of Science, 4(2), 1013-1023. doi: 10.22178/pos.31-4

61. Muhammad, S. (2011). American Muslims Perceptions of Islamic Banking in the Chicago Metropolitan Area (Doctoral dissertation). Retrieved from https://pqdtopen.proquest.com/doc/919052699.html?FMT=AI

62. Naor, M., Goldstein, S. M., Linderman, K. W., \& Schroeder, R. G. (2008). The Role of Culture as Driver of Quality Management and Performance: Infrastructure Versus Core Quality Practices. Decision Sciences, 39(4), 671-702. doi: 10.1111/j.1540-5915.2008.00208.x

63. Nworji, I. D., Adebayo, O., \& David, A. O. (2011). Corporate Governance and Bank Failure in Nigeria: Issues, Challenges and Opportunities. Research Journal of Finance and Accounting, 2(2), 1-19.

64. Oh, H. J., Ozkaya, E., \& LaRose, R. (2014). How does online social networking enhance life satisfaction? The relationships among online supportive interaction, affect, perceived social support, sense of community, and life satisfaction. Computers in Human Behavior, 30, 69-78. doi: 10.1016/j.chb.2013.07.053

65. Olayemi, A. A. M. (2011). The Legality of Islamic Banking in Nigeria: A Critical Approach. SSRN Electronic Journal. doi: 10.2139/ssrn.1941010 
66. Olson, D., \& Zoubi, T. (2017). Convergence in bank performance for commercial and Islamic banks during and after the Global Financial Crisis. The Quarterly Review of Economics and Finance, 65, 71-87. doi: 10.1016/j.qref.2016.06.013

67. Oseni, U. A., \& Ahmad, A. U. F. (2016). Towards a global hub. International Journal of Law and Management, 58(1), 48-72. doi: 10.1108/ijlma-08-2014-0052

68. Pallant, J. (2016). SPSS survival manual: a step by step guide to data analysis using SPSS (6th ed). Maidenhead: Open University Press.

69. Panchapakesan, P., Sai, L. P., \& Rajendran, C. (2015). Customer Satisfaction in Indian Hospitals: Moderators and Mediators. Quality Management Journal, 22(1), 10-29. doi: 10.1080/10686967.2015.11918416

70. Parasuraman, A., Zeithaml, V., \& Berry, L. (1994). Alternative scales for measuring service quality: A comparative assessment based on psychometric and diagnostic criteria. Journal of Retailing, 70(3), 201-230. doi: 10.1016/0022-4359(94)90033-7

71. Pesendorfer, J., \& Lehner, O. M. (2016). Islamic Banking and Finance as an Ethical Alternative: A Systematic Literature Review. ACRN Oxford Journal of Finance and Risk Perspectives, 5(2), 42-64.

72. P. Y. Lai, K., \& Samers, M. (2016). Conceptualizing Islamic banking and finance: a comparison of its development and governance in Malaysia and Singapore. The Pacific Review, 30(3), 405-424. doi: $10.1080 / 09512748.2016 .1264455$

73. Raza, S. A., Jawaid, S. T., \& Hassan, A. (2015). Internet banking and customer satisfaction in Pakistan. Qualitative Research in Financial Markets, 7(1), 24-36. doi: 10.1108/qrfm-09-20130027

74. Rotich, H. K., Okibo, W., \& Magara, E. (2015). Factors Influencing Customer Satisfaction as a Competitive Advantage in Commercial Banks in Kenya: A Case Study of Credit Bank Limited. The International Journal of Business \& Management, 3(5), 20-25.

75. Sanusi, L. S. (2011, January 6). Islamic finance in Nigeria: Issues and challenges. Retrieved from https://www.thenigerianvoice.com/movie/43090/islamic-finance-in-nigeria-issues-andchallenges.html

76. Sekaran, U., \& Bougie, R. (2016). Research methods for business: a skill building approach (7th ed.). Hoboken: John Wiley \& Sons.

77. Shemwell, D. J., Yavas, U., \& Bilgin, Z. (1998). Customer-service provider relationships: an empirical test of a model of service quality, satisfaction and relationship-oriented outcomes. International Journal of Service Industry Management, 9(2), 155-168. doi: 10.1108/09564239810210505

78. Siyanbola, T. T. (2013). Islamic Banking as a Panacea for Economic Instability in Nigeria. Nigerian Chapter of Arabian Journal of Business and Management Review, 1(3), 69-89. doi:

10.12816/0003627

79. Souiden, N., \& Rani, M. (2015). Consumer attitudes and purchase intentions toward Islamic banks: the influence of religiosity. International Journal of Bank Marketing, 33(2), 143-161. doi: 10.1108/ijbm-10-2013-0115

80. Sudin, H., \& KuMajdi, Y. (2013). Islamic Banking in Thailand: Prospects and Challenges. International Journal of Islamic Financial Services, 5(2), 52-63.

81. Tahir, I. M., \& Abu Bakar, N. M. (2007). Service Quality Gap and Customers' Satisfactions of Commercial Banks in Malaysia. International Review of Business Research Papers, 3(4), 327-336.

82. Torku, P. (2015). A correlational study of manager leadership styles and service quality in Ghanaian banks (Doctoral dissertation). Phoenix: University of Phoenix.

83. Triki, T., Kouki, I., Dhaou, M. B., \& Calice, P. (2017). Bank regulation and efficiency: What works for Africa? Research in International Business and Finance, 39, 183-205. doi:

10.1016/j.ribaf.2016.07.027 
84. Ahmad, N., Usman Awan, M., Raouf, A., \& Sparks, L. (2009). Development of a service quality scale for pharmaceutical supply chains. International Journal of Pharmaceutical and Healthcare Marketing, 3(1), 26-45. doi: 10.1108/17506120910948494

85. Aliyu, S. U. (2012, November). Islamic banking and finance in Nigeria: Issues, challenges, and opportunities. Retrieved from https://mpra.ub.unimuenchen.de/42573/1/MPRA_paper_42573.pdf

86. Hair Jr, J., Sarstedt, M., Hopkins, L., \& G. Kuppelwieser, V. (2014). Partial least squares structural equation modeling (PLS-SEM). European Business Review, 26(2), 106-121. doi: 10.1108/ebr-102013-0128

87. Yin, R. K. (2014). Case Study Research: Design and Methods (5th ed.). Los Angeles: Sage.

88. Yudistira, D. (2004). Efficiency in Islamic banking: an empirical analysis of eighteen banks. Islamic Economic Studies, 12(1), 1-19.

89. Zeitun, R. (2012). Determinants of Islamic and Conventional Banks performance in GCC Countries using Panel Data analysis. Global Economy and Finance Journal, 5(1), 53-72. 